\title{
A Review of the Diagnosis and Management of Hepatitis E
}

\author{
P. Kar ${ }^{1, *}$ \\ R. Karna ${ }^{2}$
}

\author{
Address \\ ${ }^{*}, 1$ Department of Gastroenterology and Hepatology, Max Super Specialty Hospi- \\ tal,Ghaziabad, Delhi, New Delhi, 110017, India \\ Email: premashishkar@gmail.com \\ ${ }^{2}$ Maulana Azad Medical College \& Lok Nayak Hospital, Bahadurshah Zafar Road, \\ New Delhi, India
}

Published online: 17 July 2020

(C) Springer Science+Business Media, LLC, part of Springer Nature 2020

This article is part of the Topical Collection on Hepatitis $C$

Keywords Hepatitis E virus · Ribavirin · Pregnancy · Viral hepatitis

\begin{abstract}
Purpose of review We aim to provide the readers an up-to-date knowledge of the structure, epidemiology, and transmission followed by a detailed discussion on testing, diagnostics and management of hepatitis $E$ virus infection. We have also included a comprehensive review of hepatitis $E$ in pregnancy.

Recent findings European Association for the Study of the Liver established clinical practice guidelines for testing and treatment of suspected hepatitis $E$ virus infections in 2018. Evidence suggests chronic hepatitis $E$ may follow a course similar to hepatitis $B / C$ with progression to cirrhosis and possibly hepatocellular carcinoma in immunocompromised patients.

Summary Hepatitis $E$ virus is the most common cause of acute viral hepatitis worldwide. A combination of serology and nucleic acid amplification testing is the recommended strategy for suspected patients. Ribavirin therapy for a period of 3 months is the drug of choice for severe acute hepatitis, acute-on chronic liver failure, and chronic infections from hepatitis E virus in immunocompromised patients who are unresponsive to decreased immunosuppression. PEGylated interferon a can be used for ribavirin-resistant liver transplant patients with chronic hepatitis E. Further research in therapeutic options is essential considering the stormy course of hepatitis $E$ infection during pregnancy and teratogenicity of all available options.
\end{abstract}

\section{Introduction}

Hepatitis E virus (HEV) causes acute hepatitis and acute liver failure (ALF) and is the most common cause of acute viral hepatitis worldwide. It was discovered in the early 1980 s when sera of patients 
suspected of viral hepatitis during an outbreak in Kashmir province of India tested negative for hepatitis $A$ and $B[1,2]$. This enterically transmitted non-A non-B hepatitis virus was termed as hepatitis $\mathrm{E}$ virus, with " $\mathrm{E}$ " standing for its association with epidemics and enteric mode of transmission. The article aims to provide the readers with up-to-date knowledge and recent advances in the clinical aspects of hepatitis E virus infection focusing mainly on diagnostics and management options.

\section{Structure of HEV}

HEV is a member of the Orthohepevirus genus and belongs to the Hepeviridae family. It is a small, non-enveloped 27-34-nm diameter particle with an icosahedral capsid. The virus was first isolated in the 1980s, from stool suspension of HEVinfected patients, and the excreted form of HEV in stool was found to be non-enveloped [3, 4]. Recently, enveloped forms of the virus have been identified in the blood of patients during viremia [5]. The virus gets enveloped in the membrane obtained from the host cell [5]. The enveloped virus particles do not get neutralized by antibodies and help the virus survive in the host [4].

The virus genome is $7.2 \mathrm{~kb}$, linear, single-stranded, positive-sense RNA, with a 7-methylguanine cap at $5^{\prime}$ end, 3 open reading frames, namely, orf 1-3, in between and a poly adenine tail at the other end. ORF 1 is responsible for encoding nonstructural proteins, responsible for RNA replication including RNA helicase and RNA-dependent RNA polymerase [6]. ORF2 encodes structural proteins responsible for viral capsid formation [6]. These structural proteins represent antigenic sites against which immune response can develop, hence are potential antigens for vaccine development $[7,8]$. ORF3 protein is found in blood-borne enveloped HEV particles only, responsible for viral replication, survival, and extrusion from the host cell [6].

\section{Epidemiology}

HEV infection occurs throughout the world but predominantly is associated with waterborne outbreaks in Asia and Africa $[9,10]$. There are seven genotypes of HEV, viz. HEV 1-7, but only a single serotype. HEV 1-4 are known to infect humans, while HEV 57 have animals as their host only. There are two different epidemiological patterns of HEV. HEV genotypes 1 and 2 cause outbreaks, mostly in hyperendemic regions of the world. Mostly young adults are affected, and the disease is particularly troublesome for pregnant women who develop a very severe form of the disease $[11 \bullet \bullet]$. Genotype 1 causes outbreaks in Asia (south, southeast, and central) and North Africa while genotype 2 is usually located in Mexico and western parts of Africa [12•]. Using epidemiological tools and mathematical models, it has been estimated that HEV 1 and HEV 2 cause together approximately 20.1 million (95\% credible interval 2.8-37.0 million) cases in Asia and Africa, with acute hepatitis E accounting for 3.4 million cases [13]. HEV infection is also estimated to cause 70,000 deaths from acute liver failure and 3000 stillbirths [13]. In the developed parts of the world, such as Europe, the USA, and some highincome areas in Asia, the infection is predominantly caused by HEV 3 [12•]. HEV 4 usually causes infection in China and Japan [14,15].

\section{Transmission}

Outbreaks from genotype 1 and 2 occur through the fecal-oral route due to fecal contamination of drinking water [3, 10]. HEV 3 and HEV 4 cause only sporadic cases in less endemic parts of the world, mostly from direct or indirect animal contacts, and consumption of undercooked animal products $[11 \bullet \bullet]$. Undercooked or raw pork meat, liver, and infected cow's milk are some known sources of HEV infection in these regions [12•]. Though relatively less common, person to person transmission of HEV is also known. It occurs through transfusion of blood, blood products, solid organ transplant, and via vertical transmission $[16 \bullet, 17,18 \bullet]$. Transfusiontransmitted HEV infection accounts for $<1 \%$ of all HEV infections in the UK [12•]. Many other European nations, China, and Japan have reported cases of transfusion-transmitted HEV caused by genotypes 3 and 4 predominantly [19•, 20,21]. Transfusiontransmitted HEV infection usually causes an asymptomatic or mild infection but may cause chronic infection in immunocompromised individuals [21]. Vertical transmission of HEV causes adverse effects on fetus including intrauterine demise or neonatal mortality. Khurro et al. first demonstrated evidence of vertical transmission in 5 out of 8 babies in mothers who developed HEV infection during the third trimester [22]. In another study, Kumar et al. demonstrated $100 \%$ transmission rates from HEVinfected mothers to fetus [23]. 


\section{HEV testing}

\section{Who should be tested?}

European Association for the Study of the Liver (EASL) recommends considering HEV infection as a cause of viral hepatitis and as an important differential diagnosis to drug-induced liver injury in all patients $[24 \bullet \bullet]$. Also, people with hepatitis returning from areas endemic to HEV genotype 1 and 2 should be tested. Certain population groups like pregnant women, immunocompromised-like malignancy, and people on immunosuppressants are at high risk for devastating liver disease from HEV infection. Hence, it is imperative to test them upon suspicion of viral hepatitis. EASL recommends testing for HEV during flares up of chronic liver disease and immunocompromised patients or blood recipients with abnormal LFTs $[24 \bullet \bullet]$. In many countries around the world, either universal screening of blood or targeted screening for the high-risk recipient is being done. EASL recommends screening blood donors for HEV

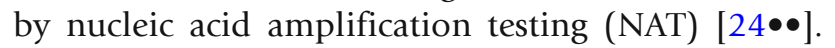
Also, HEV has extrahepatic manifestations, including neurologic, renal, hematological, and pancreatic injury. EASL recommends testing for HEV as a causative agent for neuralgia amyotrophy and GuillainBarre syndrome and suggested testing for

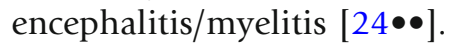

\section{Diagnostic tests}

Since the research work in the field of HEV infection picked up in the last 20 years, diagnostic testing for HEV infection has become more refined. However, it is still marred with a lack of commercial kits in many parts of the world, non-standardization of the diagnostics, and wide variability in the results achieved. In the USA, no testing kit has been licensed for commercial usage.

The diagnosis of HEV infection can be established through direct or indirect testing. The direct tests aim to detect either HEV ribonucleic acid (RNA) or viral capsid antigens in the blood. Since they detect parts of the viral particles itself, the specificity of these tests is usually high, but sensitivity is low. The indirect tests are based upon human immune response against HEV particles, i.e., anti-HEV antibodies. Hence, these tests usually have high sensitivity but low specificity. A summary of available tests for HEV infection is represented in Table 1.

\section{Indirect tests}

The indirect tests for HEV rely upon the human immune response to generate antibodies against antigenic proteins of HEV. The antigenic proteins used in the assays are recombinant ORF2 and/or ORF3 protein of viral capsid, from HEV 1 genotype [25]. Both IgM and IgG types of antibodies can be detected in these patients; however, the performances and validity of both assays are under question [26]. IgM anti-HEV antibodies develop nearly 4 weeks after the infection and can be detected in the sera for nearly 6 months, hence indicating an acute or recent infection from HEV. IgG antibodies usually also develop simultaneously with IgM antibodies early after the infection and last for years, indicating either a recent or past infection [27]. The utility of these assays is limited by their non-standardization and discordance between different kits. Sometimes, in a subset of the infected population, both IgM and IgG antibodies may be negative in HEV RNA-positive patients [4]. Also, these antibodies may wane with time, thus limiting their role for diagnostic and epidemiological purposes [28]. In a study by Abranavel et al., the specificity of IgM antiHEV was $\geq 99.5 \%$ while the specificity of IgG anti-HEV was $89.5 \%$ and $97.8 \%$ for two different diagnostic kits [29]. The testing kits for the detection of IgM antibodies had a higher sensitivity of $80-90 \%$ in immunocompetent while it was lower among immunocompromised patients viz. 85-87.5\% [29]. The sensitivity of IgG detection kits among immunocompetent patients was 80$90 \%$ while it fell dramatically to $15-45 \%$ in immunocompromised patients, rendering the test practically useless [29]. Also, there was no correlation between HEV RNA levels and IgG anti-HEV antibody levels [29]. The limits of detection of various anti-HEV IgG detection kits available commercially worldwide vary from 0.25 to 2.5 World Health Organization (WHO) units per ml. Using assays with a lower detection limit of 0.25 WHO units per $\mathrm{ml}$ gives a more elaborate estimation of the prevalence of HEV infection [30]. National Institute for Biological Standards and Control established the WHO reference reagent for $\mathrm{HEV}$ detection kit. Experts have suggested that waning anti-HEV IgG antibody levels after the natural course of disease or vaccination could pose a risk for reinfection [31].

Rapid, technically simpler, cheaper alternatives to serological or RNA-based tests have been gaining attention in recent times. Using IgM capture format, an immunochromatographic assay for detecting IgM anti- 
Table 1. A summary of available tests for HEV infection

\begin{tabular}{|c|c|c|c|c|c|}
\hline $\begin{array}{l}\text { Test } \\
\text { name }\end{array}$ & $\begin{array}{l}\text { Time from } \\
\text { infection to } \\
\text { positive }\end{array}$ & $\begin{array}{l}\text { Duration of } \\
\text { clinical } \\
\text { usefulness }\end{array}$ & Sensitivity & Specificity & Comments \\
\hline $\begin{array}{l}\text { Anti-HEV } \\
\text { IgM }\end{array}$ & $\sim 4$ weeks & 6-9 months & $\begin{array}{l}\text { Immunocompromised: } \\
85-87.5 \% \\
\text { Immunocompetent: } \\
80-90 \%\end{array}$ & $\geq 99.5 \%$ & $\begin{array}{l}\text { Usually first test } \\
\text { to be considered }\end{array}$ \\
\hline $\begin{array}{l}\text { Anti-HEV } \\
\text { IgG }\end{array}$ & $\sim 4$ weeks & years & $\begin{array}{l}\text { Immunocompromised: } \\
\text { 15-45\% } \\
\text { Immunocompetent: } \\
80-90 \%\end{array}$ & $89-98 \%$ & $\begin{array}{l}\text { Useful for seroepidemiological } \\
\text { studies; not clinically useful }\end{array}$ \\
\hline $\begin{array}{l}\text { HEV } \\
\text { Capsid }\end{array}$ & antigen & 2 weeks & 4-5 weeks & $88-99 \%$ & $100 \%$ \\
\hline $\begin{array}{l}\text { Low cost } \\
\text { and easy } \\
\text { to } \\
\text { perform; } \\
\text { can be }\end{array}$ & $\begin{array}{l}\text { considered } \\
\text { for blood } \\
\text { screening }\end{array}$ & & & & \\
\hline HEV RNA & 2 weeks & 4-5 weeks & - & - & $\begin{array}{l}\text { Gold standard test; useful in } \\
\text { immunocompromised and } \\
\text { seronegative patients }\end{array}$ \\
\hline
\end{tabular}

HEV antibodies have been developed (ASSURE ${ }^{\circledR}$ HEV IgM Rapid Test; MP Biomedical, Singapore) [32]. It has a sensitivity of $93 \%$ and specificity of $99.7 \%$, established based upon data obtained from a study in Nepal and Indonesia (Genotype1) [32]. While, in another study, during a predominant genotype 3 infection in France, the kit showed sensitivity and specificity of $82 \%$ and $100 \%$ respectively [33].

\section{Direct tests}

\section{HEV RNA}

HEV RNA detection in blood or stool is the gold standard for the detection of HEV infection. It becomes detectable even before the patient becomes clinically symptomatic and may persist for nearly 4 weeks in the blood and 6 weeks in the feces [12•]. Most commercially available assays for detecting HEV RNA are based upon NAT. These NAT-based assays include reverse transcriptase polymerase chain reaction (RT-PCR), real-time PCR, and loopmediated isothermal amplification assay [34, 35]. The real-time RT-PCR methods are more sensitive than nested RT-PCR methods [36]. These methods employ amplification of specific genome sequences mostly ORF3, followed by a nucleotide probe [37]. The limit of detection of available RNA probes is $7-$ $80 \mathrm{IU} / \mathrm{ml}[35,37]$. Characterization of HEV genotypes or subgenotypes is mostly used for epidemiological purposes, and their clinical significance is yet to be determined. Even though it is the most specific method of establishing HEV infection, its utility is mostly limited by high cost, the requirement of specialized tools and expertise, and limited resources in areas with a high burden of the disease. Subject experts and gastroenterologists have suggested HEV RNA testing in the following clinical scenarios [4]:

1. Blood screening

2. Suspected chronic HEV infection with negative serology

3. Non-hepatic presentations to confirm infection

4. HEV infection diagnosis in immunocompromised patients, with negative serology

5. Monitoring response to antivirals

6. Before genotyping and for epidemiological purposes 


\section{Capsid antigen detection}

Viral capsid antigen can be detected in the blood of those infected with HEV even before the patient becomes clinically symptomatic and persists for approximately 4 weeks. Testing for capsid antigen is technically less demanding and can be performed even without molecular detection laboratories. It can be detected using an indirect sandwich enzyme immunoassay, with an estimated sensitivity of $91 \%$ and specificity of $100 \%$ [38]. Studies have demonstrated waning levels of capsid antigen in blood of patients with HEV infection correlated with rising levels of anti-HEV antibodies [39]. Thus, it has a lower sensitivity for the detection of acute infection than HEV RNA and IgM anti-HEV [39]. However, ease of performing the diagnosis combined with a lower cost than RNA detection makes it an attractive option for blood screening and in early diagnosis of HEV infection.

\section{Recommendations}

Experts suggest testing for anti-HEV IgM initially for suspected HEV infection [12•]. A positive test suggests recent or active infection, after which HEV RNA analysis can be done for molecular characterization, while negative test results rule out the disease. The recommended algorithm differs slightly in immunocompromised patients considering the weakened immune response that develops in these patients. Patients who test negative for IgM anti-HEV should be tested for HEV RNA. Positive results for either HEV RNA or anti-HEV IgM confirms recent or active infection, but negative results for both the tests are required to rule out a disease. Also, since immunocompromised patients are at high risk of developing chronic HEV infection, HEV RNA testing in both blood and stools must be done to determine viral clearance before the patient is declared free from infection.

\section{Treatment}

Management of HEV infection depends upon its clinical presentation. The spectrum of clinical presentation ranges from asymptomatic infections through icteric and anicteric acute hepatitis to chronic hepatitis or liver failure. HEV infection is usually a self-limiting infection, and complete resolution is seen usually without any antiviral therapy. The management of icteric or anicteric viral hepatitis is mostly conservative and focuses on self- resolution of the disease. However, HEV may have a stormy course of disease in the form of ALF, more so in pregnant women. Interestingly, a study by Shalimar et al. has revealed HEV ALF to have lower rates of cerebral edema, infections, seizures, and mortality as compared to other causes of ALF [40].

In recent years, ribavirin has gained some spotlight in the treatment of HEV infection. Ribavirin, a prodrug, is a guanosine analog and when metabolized acts as a nucleotide analog to deplete intracellular guanosine triphosphate and, subsequently, RNA replication. It has also been postulated that ribavirin acts by inhibiting viral replication and has a role in immune modulation, increased expression of interferon stimulation genes, and mutagenesis $[41,42]$. There have been reports of improvement in patients with severe acute hepatitis $\mathrm{E}$ with treatment with ribavirin $[43,44]$. Hence, ribavirin therapy can be considered for severe acute hepatitis or

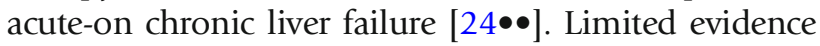
with ribavirin suggests a rapid improvement in liver enzyme profile and a decline in HEV RNA levels in patients with HEV genotype 1 and 3 infections. However, its usage in patients with severe acute hepatitis $E$ is based upon anecdotal evidence only.

The existence of chronic HEV infection was first reported in 2008 among solid organ transplant patients [45]. Chronic HEV infection is seen clinically in immunosuppressed patients especially with defective $\mathrm{T}$ cell response arm, including patients on immunosuppressant for organ transplants, HIV, and hematological malignancies [45-47]. Chronic HEV infection is defined as the detection of HEV RNA in blood or stools or any

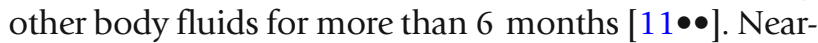
ly, $10 \%$ of immunosuppressed chronic HEV-infected patients developed fibrosis and chronic liver disease within a few years $[48,49]$. Recently, a case of hepatocellular carcinoma in a patient with HEV-associated cirrhosis has been described [50•].

The management of chronic HEV infection in immunocompromised requires careful assessment of risks and benefits. The first-line management option in such cases is to boost immune response either by reducing the dose of immunosuppressant or initiating antiretroviral therapy along with HEV RNA monthly monitoring for 3 months [12•]. This the preferred approach and is successful in nearly $33 \%$ of patients but must be balanced against the possibility of solid organ rejection [49]. In case the risks of reducing immunosuppressants outweigh the benefits, or the first-line option fails, oral ribavirin is the drug of choice, usually administered 
initially for a period of 3 months. In a retrospective study analyzing the efficacy of ribavirin among 59 transplant patients with chronic hepatitis $\mathrm{E}$, drug ribavirin administered in a median dose of $\sim 8.1 \mathrm{mg} / \mathrm{kg}$ for 3 months led to a sustained virological response in $78 \%$ patients [51]. Sustained virological response is defined as undetectable serum HEV RNA at 6 months after stopping ribavirin. A fall in HEV RNA $\geq 0.5 \log 10$ copies $/ \mathrm{ml}$ on day 7 of ribavirin is said to be a predictor of sustained virological response [52]. However, the study did not show any difference in sustained virological response between those treated for $\leq 3$ months from those treated for $>3$ months [51]. Hence, patients with solid organ transplants who fail to clear HEV RNA within 3 months can be considered for ribavirin treatment. Moreover, the patients who relapsed exhibited sustained virological response after treatment with ribavirin for 6 more months [51]. Though the exact dose and duration of ribavirin therapy for chronic HEV infection is not defined, treatment courses of 3 to 6 months are typically used. Since chronic hepatitis E patients frequently suffer from anemia and kidney disease and ribavirin pharmacokinetics depend on kidney function, the dose and duration of the therapy must be adjusted according to hemoglobin and eGFR levels in these patients [53]. EASL recommends treating patients with chronic HEV and

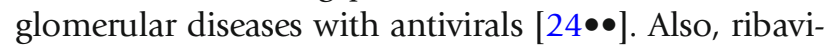
rin resistance is now being reported with increasing frequency in patients with chronic hepatitis $\mathrm{E}$ due to G1634R mutation in RNA polymerase [54]. In an in vitro system, ribavirin shows a synergistic effect with mycophenolate, which is an inosine monophosphate dehydrogenase inhibitor in depreciating HEV RNA replicative machinery; however, no such evidence has been found in vivo till date [55].

Sofosbuvir, a nucleotide analog that brought revolutionary changes in the treatment of the hepatitis $\mathrm{C}$ virus, has been found to decrease genotype $3 \mathrm{HEV}$ replication in vitro [56]. Valk et al. reported a case of chronic hepatitis $\mathrm{E}$ in an immunocompromised patient where sofosbuvir showed antiviral activity [57•]. Wezel et al. observed that sofosbuvir showed antiviral activity in chronic HEV-infected three solid organ transplant patients but failed to achieve sustained virological response [58].

Interferon $\alpha$ (IFN $\alpha)$ is another therapeutic option for chronic hepatitis $\mathrm{E}$ and has shown efficacy in achieving a sustained virological response in patients with liver transplants and hemodialysis [59-61]. However, IFN $\alpha$ is contraindicated in patients with transplant recipients due to the risk of acute rejection [62]. Limited evidence exists for the treatment of chronic HEV infection in HIV or hematological disease with IFN $\alpha$, ribavirin, or both, which could form the template for further research and clinical trials to determine the dose, route, and efficacy of available treatment options. In a case report, corticosteroids were associated with biochemical recovery in patients with HEV infection and may prevent the progression of severe hepatitis to liver failure [63].

\section{HEV in pregnancy}

HEV infection in pregnancy caused by genotypes 1 and 2 in developing countries has been associated with poor fetal-maternal outcomes as compared to the relatively benign course of illness in the Western world where infections are more commonly caused by genotypes 3 and $4[64 \bullet]$. Data from our previous study shows HEV infection to have a higher incidence, severe and aggressive course of illness, and poor outcomes during pregnancy [65]. In pregnant women, HEV was the leading cause of acute viral hepatitis and acute liver failure accounting for $80.36 \%$ (442/550) and $73.38 \%$ (102/139) of cases, respectively. HEV-related liver infection accounted for $98 / 129(75.96 \%)$ death cases, whereas non-HEV liver infection accounted for 31/129 (24.04\%) death cases in comparison among pregnant women. The course of illness is worse if the infection is acquired in the third trimester of pregnancy [64•]. Maternal mortality varies from 15 to $25 \%$ for genotype 1 infection acquired in the third trimester [66]. Lifethreatening complications of ALF viz. coagulopathy, DIC, encephalopathy, and cerebral edema can be seen in $70 \%$ of HEV-infected pregnant women [67]. An interesting study from Egypt showed high anti-HEV prevalence $(84.3 \%$ ) among pregnant women, but many of them never recalled an episode of viral hepatitis [68]. The differences in severity and prognosis in the different parts of the world could be accounted for by infections caused by different genotypes, differences in the rates of childhood infections, healthcare facility, and maternal nutritional state.

Fetal complications of HEV infection range from preterm delivery, intrauterine death, and poor infant survival rates $[69,70]$. In a study from India, it was observed that $56 \%$ of infants born to HEV-infected mothers die in utero or soon after birth [10]. In another study, the authors observed that 15 to $50 \%$ of such infants die within a week of birth [70,71]. In a study by Rayis et al., out of 39 pregnant women with HEV infection, there were 14 intrauterine deaths and 9 premature deliveries [72]. In a retrospective study by Banait 
et al. among 42 pregnant women with HEV-induced ALF, 23 women could not survive [73]. Out of 42 women, 22 delivered with spontaneous delivery in 13 women and induction of labor in 9 women for intrauterine demise [73]. The study showed better outcomes in terms of survival among women with encephalopathy who delivered [73].

Currently, the management of HEV infection in pregnancy is mainly supportive. The use of ribavirin and PEGylated IFN $\alpha$ among pregnant women with HEV has not been explored due to the high risks of teratogenicity. In recent times, the increasing interest in sofosbuvir for HEV in pregnancy is something to look out for, since it is a pregnancy category B drug [64•]. Also, termination of pregnancy is useful in immunologically mediated liver failures in pregnancy such as HELLP syndrome and acute fatty liver of pregnancy (AFLP). Currently, there is no evidence of any therapeutic benefit of termination of pregnancy in HEV-induced ALF. EASL recommends treatment of HEV genotypes 1 and 2 infections during pregnancy in high-dependency units and prompt transfer to Liver Transplant Unit if liver failure

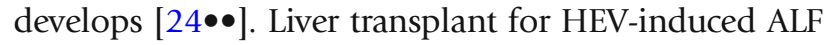
during pregnancy is rare, and outcome, complications, and timing of delivery in such a scenario remain unexplored.

\section{HEV prevention}

Since HEV infection is water and foodborne in hyperendemic and low endemic areas respectively, preventive strategies are focused on preventing water and food contamination. In hyperendemic areas of the world, preventive measures focus on improvement in drinking water quality via chlorination and sanitation hygiene. In low endemicity areas, safe food handling and thorough cooking are the cornerstones of preventing food-based transmission. Immunosuppressed and chronic liver disease patients are advised to refrain from eating raw,

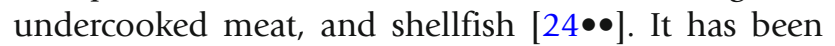

recommended to cook meat thoroughly at temperatures

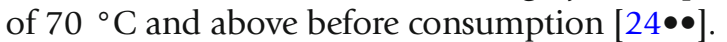

There has been a considerable amount of research in the past 20 years in the field of HEV vaccination. One of the structural proteins, orf2, responsible for capsid formation, represents antigenic sites against which immune response can develop. Different strains of HEV share neutralizing epitopes on orf 2 capsid proteins, thus providing cross-reactivity and potential antigens for vaccine development $[8,74]$. The first HEV vaccine to be tested in randomized, double-blind, controlled, phase II trial among 2000 Nepalese men showed 95.5\% protection during a median follow up of 804 days [75]. The vaccine contained a 56-kilo Dalton truncated (amino acid 112-607) orf2 protein administered in three doses at 0-1-6 months [75]. The vaccine did not undergo further development. Another vaccine called HEV 239 (Hecolin $\left.{ }^{\circledR}\right)$, tested in a double-blind, controlled, randomized phase III trial among 112,604 healthy men and women, is available commercially in China since 2012 [76]. The vaccine contains $26 \mathrm{k}$ Dalton recombinant, truncated (amino acid 368-606) orf2 protein, administered $30 \mu \mathrm{g}$ intramuscularly at 0-1-6 months, and showed a protection rate of $95.5 \%$ after a year and cross-protection for HEV 1 and 4 [76]. Long-term follow up of the recruited subjects has shown the vaccine to be protective even after 4 years and safe in women [77]. However, the vaccine is not available in other countries. The 30th Global Advisory Committee on Vaccine Safety, WHO has recommended a phase IV trial of the vaccine and further data on its safety in special population groups including children and elderly [78]. Experts recommend selective vaccination against HEV in certain high-risk groups such as immunosuppressed population, persons with chronic liver disease, pregnant women in disease-endemic areas, travelers from lowendemicity areas to high-endemicity areas and general

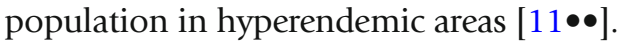

\section{Conclusions}

Hepatitis E virus leads to outbreaks in developing countries and causes significant morbidity and mortality in immunocompromised and pregnant females. Our knowledge of HEV infection has increased dramatically over the past 20 years. A combination of serology and NAT is the recommended testing strategy for suspected patients. Further research into therapeutic options for 
treating hepatitis E infection is the need of the hour. Oral ribavirin is the initial drug of choice for severe acute hepatitis, acute-on chronic liver failure, and chronic hepatitis E. PEGylated interferon $\alpha$ can be used for ribavirin-resistant liver transplant patients with chronic hepatitis E. However, no further treatment option is available for immunocompromised organ transplant patients who fail initial ribavirin therapy. Sofosbuvir shows promise as antiviral in immunocompromised patients with chronic hepatitis $\mathrm{E}$, but more evidence would be needed before being considered as a reliable therapeutic option in ribavirin-resistant patients. There is no available treatment option for HEV infection during pregnancy, which takes a very stormy course sometimes. Our further focus should be on finding appropriate management options for HEV infection during pregnancy and for ribavirin-resistant infections.

\section{Author's contribution}

Premashis Kar: conceptualization, planning, literature search, manuscript drafting, revision and editing Rahul Karna: literature search, manuscript drafting, revision and editing.

\section{Compliance with ethical standards}

Conflict of interest

Kar P declares that he has no conflict of interest. Karna R declares that he has no conflict of interest.

Human and animal rights and informed consent

This article does not contain any studies with human or animal subjects performed by any of the authors.

\section{References}

Papers of particular interest, published recently, have been

highlighted as:

- Of importance

-• Of major importance

1. Wong DC, Purcell RH, Sreenivasan MA, Prasad SR, Pavri KM. Epidemic and endemic hepatitis in India: evidence for a non-a, non-B hepatitis virus aetiology. Lancet. 1980;2(8200):876-9.

2. Khuroo MS. Study of an epidemic of non-a, non-B hepatitis. Possibility of another human hepatitis virus distinct from post-transfusion non-a, non-B type. Am J Med. 1980;68(6):818-24.

3. Balayan MS, Andjaparidze AG, Savinskaya SS, Ketiladze ES, Braginsky DM, Savinov AP, et al. Evidence for a virus in non-a, non-B hepatitis transmitted via the fecal-oral route. Intervirology. 1983;20(1):23-31.
4. Aggarwal R, Goel A. Advances in hepatitis E - I: virology, pathogenesis and diagnosis. Expert Rev Gastroent Hepatol. 2016;10(9):1053-63.

5. Feng Z, Lemon SM. Peek-a-boo: membrane hijacking and the pathogenesis of viral hepatitis. Trends Microbiol. 2014;22(2):59-64.

6. Holla R, Ahmad I, Ahmad Z, Jameel S. Molecular virology of hepatitis E virus. Semin Liver Dis. 2013;33(1):3-14.

7. Guu TSY, Liu Z, Ye Q, Mata DA, Li K, Yin C, et al. Structure of the hepatitis E virus-like particle suggests mechanisms for virus assembly and receptor binding. PNAS. 2009;106(31):12992-7. 
8. Tang X, Yang C, Gu Y, Song C, Zhang X, Wang Y, et al. Structural basis for the neutralization and genotype specificity of hepatitis E virus. PNAS.

2011;108(25):10266-71.

9. Naik SR, Aggarwal R, Salunke PN, Mehrotra NN. A large waterborne viral hepatitis E epidemic in Kanpur. India Bull World Health Organ. 1992;70(5):597-604.

10. Viswanathan R. Infectious hepatitis in Delhi (195556): a critical study-epidemiology. Indian J Med Res. 1957;45(Suppl 1):1-29.

11.• Kamar N, Izopet J, Pavio N, Aggarwal R, Labrique A, Wedemeyer $\mathrm{H}$, et al. Hepatitis E virus infection. Nat Rev Dis Prim. 2017;3(1):1-1.

An up-to-date review of hepatitis $\mathrm{E}$ virus infection with comprehensive diagnosis and treatment.

12.• Goel A, Aggarwal R. Advances in hepatitis E - II: epidemiology, clinical manifestations, treatment and prevention. Expert Rev Gastroenterol Hepatol. 2016;10(9):1065-7.

A comprehensive review of recent advances in epidemiology, clinical manifestations, treatment and prevention.

13. Rein DB, Stevens GA, Theaker J, Wittenborn JS, Wiersma ST. The global burden of hepatitis E virus genotypes 1 and 2 in 2005. Hepatology. 2012;55(4):988-97.

14. Inagaki Y, Oshiro Y, Tanaka T, Yoshizumi T, Okajima $\mathrm{H}$, Ishiyama $\mathrm{K}$, et al. A nationwide survey of hepatitis $\mathrm{E}$ virus infection and chronic hepatitis $\mathrm{E}$ in liver transplant recipients in Japan. EBioMedicine. 2015;2(11):1607-12.

15. Dai X, Dong C, Zhou Z, Liang J, Dong M, Yang Y, et al. Hepatitis E virus genotype 4, Nanjing, China, 20012011. Emerg Infect Dis. 2013;19(9):1528-30.

16. Pourbaix A, Ouali N, Soussan P, Afonso AMR, Péraldi $\mathrm{M}-\mathrm{N}$, Rondeau E, et al. Evidence of hepatitis E virus transmission by renal graft. Transpl Infect Dis. 2017;19(1):e1262.

First evidence of hepatitis E virus transmission through renal graft.

17. Kamar N, Bendall R, Legrand-Abravanel F, Xia N-S, Ijaz S, Izopet J, et al. Hepatitis E. Lancet. 2012;379(9835):2477-88.

18. Murkey JA, Chew KW, Carlson M, Shannon CL, Sirohi D, Sample HA, et al. Hepatitis E virus-associated meningoencephalitis in a lung transplant recipient diagnosed by clinical metagenomic sequencing. Open Forum Infect Dis. 2017;4(3)

First evidence of hepatitis E virus transmission through transplanted lung.

19.• Satake M, Matsubayashi K, Hoshi Y, Taira R, Furui Y, Kokudo N, et al. Unique clinical courses of transfusiontransmitted hepatitis E in patients with immunosuppression. Transfusion. 2017;57(2):280-.

The article shows relatively benign course of transfusion transmitted hepatitis $\mathrm{E}$ in immunocompromised patients. 20. Zhang L, Jiao S, Yang Z, Xu L, Liu L, Feng Q, et al. Prevalence of hepatitis $\mathrm{E}$ virus infection among blood donors in mainland China: a meta-analysis. Transfusion. 2017;57(2):248-57.
21. Hewitt PE, Ijaz S, Brailsford SR, Brett R, Dicks S, Haywood B, et al. Hepatitis E virus in blood components: a prevalence and transmission study in Southeast England. Lancet. 2014;384(9956):1766-73.

22. Khuroo MS, Kamili S, Jameel S. Vertical transmission of hepatitis E virus. Lancet. 1995;345(8956):1025-6.

23. Kumar RM, Uduman S, Rana S, Kochiyil JK, Usmani A, Thomas L. Sero-prevalence and mother-to-infant transmission of hepatitis E virus among pregnant women in the United Arab Emirates. Eur J Obstet Gynecol Reprod Biol. 2001;100(1):9-15.

$24 . \bullet \quad$ EASL. Clinical Practice Guidelines on hepatitis E virus infection. J Hepatol. 2018;68(6):1256-7.

An expert committee evidence-based guidelines focusing on testing and management of hepatitis E infection by European Association for the Study of the Liver.

25. Aggarwal D, R. Diagnosis of hepatitis E. Nat Rev Gastroenterol Hepatol. 2013;10(1):24-33.

26. Norder H, Karlsson M, Mellgren Å, Konar J, Sandberg E, Lasson A, et al. Diagnostic performance of five assays for anti-hepatitis E virus IgG and IgM in a large cohort study. J Clin Microbiol. 2016;54(3):549-55.

27. Khuroo MS, Kamili S, Dar MY, Moecklii R, Jameel S. Hepatitis E and long-term antibody status. Lancet. 1993;341(8856):1355.

28. Myint KSA, Endy TP, Shrestha MP, Shrestha SK, Vaughn DW, Innis BL, et al. Hepatitis E antibody kinetics in Nepalese patients. Trans R Soc Trop Med Hyg. 2006;100(10):938-41.

29. Abravanel F, Chapuy-Regaud S, Lhomme S, Miedougé M, Peron J-M, Alric L, et al. Performance of anti-HEV assays for diagnosing acute hepatitis $\mathrm{E}$ in immunocompromised patients. J Clin Virol. 2013;58(4):624-8.

30. Bendall R, Ellis V, Ijaz S, Ali R, Dalton H. A comparison of two commercially available anti-HEV IgG kits and a re-evaluation of anti-HEV IgG seroprevalence data in developed countries. J Med Virol. 2010;82(5):799805.

31. Abravanel F, Lhomme S, Chapuy-Regaud S, Mansuy JM, Muscari F, Sallusto F. Hepatitis E virus reinfections in solid-organ-transplant recipients can evolve into chronic infections. J Infect Dis. 2014;209(12):1900-6. Myint KSA, Guan M, Chen HY, Lu Y, Anderson D, Howard T, et al. Evaluation of a new rapid immunochromatographic assay for serodiagnosis of acute hepatitis E infection. Amn J Trop Med Hyg. 2005;73(5):942-6.

33. Legrand-Abravanel F, Thevenet I, Mansuy J-M, Saune K, Vischi F, Peron J-M, et al. Good performance of immunoglobulin $\mathrm{M}$ assays in diagnosing genotype 3 hepatitis E virus infections. Clin Vaccine Immunol. 2009;16(5):772-4.

34. Lan X, Yang B, Li BY, Yin XP, Li XR, Liu JX. Reverse transcription-loop-mediated isothermal amplification assay for rapid detection of hepatitis E virus. J Clin Microbiol. 2009;47(7):2304-6.

35. Sauleda S, Ong E, Bes M, Janssen A, Cory R, Babizki M, et al. Seroprevalence of hepatitis E virus (HEV) and detection of HEV RNA with a transcription-mediated 
amplification assay in blood donors from Catalonia (Spain). Transfusion. 2015;55(5):972-9.

36. Baylis SA, Hanschmann K-M, Blümel J, Nübling CM. Standardization of hepatitis E virus (HEV) nucleic acid amplification technique-based assays: an initial study to evaluate a panel of HEV strains and investigate laboratory performance. J Clin Microbiol. 2011;49(4):1234-9.

37. Abravanel F, Chapuy-Regaud S, Lhomme S, Dubois M, Peron J-M, Alric L, et al. Performance of two commercial assays for detecting hepatitis E virus RNA in acute or chronic infections. J Clin Microbiol. 2013;51(6):1913-6.

38. Trémeaux P, Lhomme S, Chapuy-Regaud S, Peron J-M, Alric L, Kamar N, et al. Performance of an antigen assay for diagnosing acute hepatitis $\mathrm{E}$ virus genotype 3 infection. J Clin Virol. 2016;79:1-5.

39. Zhang F, Li X, Li Z, Harrison TJ, Chong H, Qiao S, et al. Detection of HEV antigen as a novel marker for the diagnosis of hepatitis E. J Med Virol. 2006;78(11):1441-8.

40. Shalimar KS, Gunjan D, Sonika U, Mahapatra SJ, Nayak B, et al. Acute liver failure due to hepatitis E virus infection is associated with better survival than other etiologies in Indian patients. Dig Dis Sci. 2017;62(4):1058-66.

41. Debing Y, Emerson SU, Wang Y, Pan Q, Balzarini J, Dallmeier K, et al. Ribavirin inhibits in vitro hepatitis E virus replication through depletion of cellular GTP pools and is moderately synergistic with alpha interferon. Antimicrob Agents Chemother. 2014;58(1):267-73.

42. Paeshuyse J, Dallmeier K, Neyts J. Ribavirin for the treatment of chronic hepatitis $\mathrm{C}$ virus infection: a review of the proposed mechanisms of action. Curr Opin Virol. 2011;1(6):590-8.

43. Gerolami R, Borentain P, Raissouni F, Motte A, Solas C, Colson P. Treatment of severe acute hepatitis E by ribavirin. J Clin Virol. 2011;52(1):60-2.

44. Goyal R, Kumar A, Panda SK, Paul SB, Acharya SK. Ribavirin therapy for hepatitis E virus-induced acute on chronic liver failure: a preliminary report. Antivir Ther. 2012;17(6):1091-6.

45. Kamar N, Selves J, Mansuy JM, Ouezzani L, Péron JM, Guitard J. Hepatitis E virus and chronic hepatitis in organ-transplant recipients. N Engl J Med. 2008;358(8):811-7.

46. Ollier L, Tieulie N, Sanderson F, Heudier P, Giordanengo V, Fuzibet J-G, et al. Chronic hepatitis after hepatitis $\mathrm{E}$ virus infection in a patient with nonHodgkin lymphoma taking rituximab. Ann Intern Med. 2009;150(6):430-1.

47. Dalton HR, Bendall RP, Keane FE, Tedder RS, Ijaz S. Persistent carriage of hepatitis E virus in patients with HIV infection. N Engl J Med. 2009;361(10):1025-7.

48. Kamar N, Mansuy JM, Cointault O, Selves J, Abravanel F, Danjoux M. Hepatitis E virus-related cirrhosis in kidney- and kidney-pancreas-transplant recipients. Am J Transplant. 2008;8(8):1744-8.
49. Kamar N, Garrouste C, Haagsma EB, Garrigue V, Pischke S, Chauvet $\mathrm{C}$, et al. Factors associated with chronic hepatitis in patients with hepatitis $\mathrm{E}$ virus infection who have received solid organ transplants. Gastroenterology. 2011;140(5):1481-9.

50. Borentain P, Colson P, Bolon E, Gauchez P, Coso D, Gerolami R. Hepatocellular carcinoma complicating hepatitis E virus-related cirrhosis. Hepatology. 2018;67(1):446-.

First case of hepatocellular carcinoma in a patient with hepatitis E virus related cirrhosis.

51. Kamar N, Izopet J, Tripon S, Bismuth M, Hillaire S, Dumortier J, et al. Ribavirin for chronic hepatitis E virus infection in transplant recipients. $\mathrm{N}$ Engl J Med. 2014;370(12):1111-20.

52. Kamar N, Lhomme S, Abravanel F, Cointault O, Esposito L, Cardeau-Desangles I. An early viral response predicts the virological response to ribavirin in hepatitis E virus organ transplant patients. Transplantation. 2015;99(10):2124-31.

53. Kamar N, Chatelut E, Manolis E, Lafont T, Izopet J, Rostaing L. Ribavirin pharmacokinetics in renal and liver transplant patients: evidence that it depends on renal function. Am J Kidney Dis. 2004;43(1):140-6.

54. Debing Y, Gisa A, Dallmeier K, Pischke S, Bremer B, Manns $M$, et al. A mutation in the hepatitis E virus RNA polymerase promotes its replication and associates with ribavirin treatment failure in organ transplant recipients. Gastroenterology. 2014;147(5):10081011.e7 quiz e15-16.

55. Wang Y, Zhou X, Debing Y, Chen K, Van Der Laan LJW, Neyts J, et al. Calcineurin inhibitors stimulate and mycophenolic acid inhibits replication of hepatitis E virus. Gastroenterology. 2014;146(7):1775-83.

56. Dao Thi VL, Debing Y, Wu X, Rice CM, Neyts J, Moradpour D, et al. Sofosbuvir inhibits hepatitis E virus replication in vitro and results in an additive effect when combined with ribavirin. Gastroenterology. 2016;150(1):82-85.e4.

57. van der Valk M, Zaaijer HL, Kater AP, Schinkel J. Sofosbuvir shows antiviral activity in a patient with chronic hepatitis E virus infection. J Hepatol. 2017;66(1):242-.

First case of Sofosbuvir demonstrating antiviral activity against hepatitis $\mathrm{E}$ virus infection in vivo.

58. van Wezel EM, de Bruijne J, Damman K, Bijmolen $\mathrm{M}$, van den Berg AP, Verschuuren EAM, et al. Sofosbuvir add-on to ribavirin treatment for chronic hepatitis E virus infection in solid organ transplant recipients does not result in sustained virological response. Open Forum Infect Dis. 2019;6(8).

59. Kamar N, Rostaing L, Abravanel F, Garrouste C, Esposito L, Cardeau-Desangles I. Pegylated interferon- $\alpha$ for treating chronic hepatitis E virus infection after liver transplantation. Clin Infect Dis. 2010;50(5):e30-3.

60. Kamar N, Abravanel F, Garrouste C, CardeauDesangles I, Mansuy JM, Weclawiak H. Three-month pegylated interferon-alpha-2a therapy for chronic 
hepatitis E virus infection in a haemodialysis patient. Nephrol Dial Transplant. 2010;25(8):2792-5.

61. Haagsma EB, Riezebos-Brilman A, van den Berg AP, Porte RJ, Niesters HG. Treatment of chronic hepatitis E in liver transplant recipients with pegylated interferon alpha-2b. Liver Transpl. 2010;16(4):474-7.

62. Rostaing L, Izopet J, Baron E, Duffaut M, Puel J, Durand $\mathrm{D}$. Treatment of chronic hepatitis $\mathrm{C}$ with recombinant interferon alpha in kidney transplant recipients. Transplantation. 1995;59(10):1426-31.

63. Manka P, Bechmann LP, Coombes JD, Thodou V, Schlattjan M, Kahraman A, et al. Hepatitis E virus infection as a possible cause of acute liver failure in Europe. Clin Gastroenterol Hepatol. 2015;13(10):1836-1842.e2.

64. Kar P, Sengupta A. A guide to the management of hepatitis E infection during pregnancy. Expert Rev Gastroenterol Hepatol. 2019;13(3):205-1.

An uptodate review of hepatitis $\mathrm{E}$ virus infection during pregnancy.

65. Karna R, Hazam RK, Borkakoti J, Kumar A, Kar P. A 5year single-center experience of hepatitis E virus infection during pregnancy. J Clin Exp Hepatol. 2020;10(2):135-8.

66. Ranger-Rogez S, Alain S, Denis F. Hepatitis viruses: mother to child transmission. Pathol Biol (Paris). 2002;50(9):568-75.

67. Khuroo MS, Kamili S. Aetiology, clinical course and outcome of sporadic acute viral hepatitis in pregnancy. J Viral Hepat. 2003;10(1):61-9.

68. Stoszek SK, Abdel-Hamid M, Saleh DA, Kafrawy SE, Narooz S, Hawash Y, et al. High prevalence of hepatitis E antibodies in pregnant Egyptian women. Trans R Soc Trop Med Hyg. 2006;100(2):95-101.

69. Krain LJ, Atwell JE, Nelson KE, Labrique AB. Fetal and neonatal health consequences of vertically transmitted hepatitis E virus infection. Am J Trop Med Hyg. 2014;90(2):365-70.

70. Patra S, Kumar A, Trivedi SS, Puri M, Sarin SK. Maternal and fetal outcomes in HEV-infected pregnant women. Ann Intern Med. 2007;147(1):28-33.
71. Rasheeda CA, Navaneethan U, Jayanthi V. Liver disease in pregnancy and its influence on maternal and fetal mortality: a prospective study from Chennai, Southern India. Eur J Gastroenterol Hepatol. 2008;20(4):362-4.

72. Rayis DA, Jumaa AM, Gasim GI, Karsany MS, Adam I. An outbreak of hepatitis E and high maternal mortality at Port Sudan. Eastern Sudan Pathogens and Global Health. 2013;107(2):66-8.

73. Banait VS, Sandur V, Parikh F, Murugesh M, Ranka P, Ramesh VS. Outcome of acute liver failure due to acute hepatitis E in pregnant women. Indian J Gastroenterol. 2007;26(1):6-10.

74. Xing L, Wang JC, Li T-C, Yasutomi Y, Lara J, Khudyakov $\mathrm{Y}$, et al. Spatial configuration of hepatitis E virus antigenic domain. J Virol. 2011;85(2):1117-24.

75. Shrestha MP, Scott RM, Joshi DM, Mammen MP Jr, Thapa GB, Thapa N, et al. Safety and efficacy of a recombinant hepatitis E vaccine. $\mathrm{N}$ Engl J Med. 2007;356(9):895-903.

76. Zhu F-C, Zhang J, Zhang X-F, Zhou C, Wang Z-Z, Huang S-J, et al. Efficacy and safety of a recombinant hepatitis E vaccine in healthy adults: a large-scale, randomised, double-blind placebo-controlled, phase 3 trial. Lancet. 2010;376(9744):895-902.

77. Zhang J, Zhang XF, Huang SJ, Wu T, Hu YM, Wang ZZ, et al. Long-term efficacy of a hepatitis E vaccine. N Engl J Med. 2015;372(10):914-22.

78. Organization WH. Global Advisory Committee on Vaccine Safety, 11-12 June 2014 = Comité consultatif mondial de la Sécurité vaccinale, 11-12 juin 2014. Weekly Epidemiological Record = Relevé épidémiologique hebdomadaire. 2014;89(29):325-35.

\section{Publisher's Note}

Springer Nature remains neutral with regard to jurisdictional claims in published maps and institutional affiliations. 